\title{
Real-time Voltammetric Assay of Cadmium Ions in Plant Tissue and Fish Brain Core
}

\author{
Suw Young Ly \\ Biosensor Research Institute, Seotl National University of Technology, Seoul 139-743, Kora. E-mail: suwyoung@snutackr \\ Received February 3, 2006
}

\begin{abstract}
Optimum analytical conditions for cyclic voltammetry (CV) and square wave (SW) stripping voltammetry were determined using mercury-mixed carbon nanotube paste electrode (PE). The results approached the microgram working ranges of $\mathrm{SW}: 10.0-80.0 \mathrm{ugL}^{-1}$ and $\mathrm{CV}: 100-700 \mathrm{ugL}^{-1} \mathrm{Cd}$ (II); working conditions of $300-$ $\mathrm{Hz}$ frequency, $100 \mathrm{mV}$ amplitude, $-1.6 \mathrm{~V}$ accumulation potential, $400 \mathrm{sec}$ accumulation time, and $40 \mathrm{mV}$ increment potential. First, analysis was performed through direct assay of cadmium ions deep into the fish's brain core and plant tissue in real time with a preconcentration time of $400 \mathrm{sec}$. The relative standard deviation of $10.0 \mathrm{mgL}^{-1} \mathrm{Cd}$ (II) observed was $0.064(n=12)$ at optimum conditions. The low detection limit $(\mathrm{S} / \mathrm{N})$ was set at $0.6 \mathrm{ugL}^{-1}\left(5.33 \times 10^{-9} \mathrm{M}\right)$. The methods can be used in direct analysis in vivo or in real-time monitoring of plant tissue.
\end{abstract}

Key Words : Cadmium ion, Voltammetry, Brain, Plant, in vivo

\section{Introduction}

In biological assays, the trace metal element is essential for normal central nervous system development and functioning. However, these redox activities have been associated with several neurodegenerative disorders' and environment toxicological contamination in mammals. ${ }^{2}$ The diagnosis of these trace metals in the brain is dependent on certain neurodegenerative diseases, e.g., Alzheimer's and Parkinson's disease.$^{3-5}$ The trace cadmium ion is particularly important in the biological matrix ${ }^{6}$ and clinical treatments of the serum, blood, or urine, because of cadmium ion's antioxidant properties and its influence on different biological activities. ${ }^{7}$ Cadmium is also present in food, especially in vegetables. ${ }^{8.9}$ Cadmium is an environmental toxin with a toxicity close to those of arsenic, mercury, and lead. ${ }^{10}$ Depending on how it is ingested, cadmium can affect functioning of lungs or kidney. ${ }^{11}$ Various analytical techniques have been developed to this end. Some of the more specialized continuous flow methods that have been developed include the CMPA-HPLC method, ${ }^{12}$ CD-HPLC analysis method, ${ }^{13}$ quadruple ion-trap gas chromatographymass spectrometry, ${ }^{1 / 4}$ and capillary electrokinetic chromatography. ${ }^{15}$ All these methods involve complicated pretreatment techniques and expensive instruments. Attempts to simplify such methods have resulted in the development of other related methods such as the electrochemical method, ${ }^{16}$ stripping voltammetry, ${ }^{17}$ and cathodic stripping voltammetry of complexes with 5-fluorouracil. ${ }^{11}$ The voltammetric method is simple and inexpensive. ${ }^{18.19}$ Nonetheless, these methods use specific properties and modified working electrode systems that are still complicated and unattainable for in vivo assay. The electrochemical method is widely used in more developed methods and is preferred for its low detection range.

In this study, the stripping voltammetric technique, which yields a faster response than other methods, is more cost efficient, and the PE electrode is handy for the in vivo assay. ${ }^{20.21}$ Sensitive preconcentration techniques were used along with a simpler mercury-composed carbon nanotube paste electrode, the mercury electrode that has been used for years in trace analysis in stripping voltammetry. ${ }^{22-24}$ Also, carbon nanotubes are commonly used in biosensors for their geometric, mechanical, and catalytic capabilities. ${ }^{25-27}$ However, common methods are used in laboratory conditions only. In this study, carbon nanotube was combined with paste electrode. The method achieved lower detection limits for $0.6 \mathrm{ugL}^{-1}\left(5.33 \times 10^{-9} \mathrm{M}\right)$ better then common paste electrode $\left(4.0 \times 10^{-8} \mathrm{M}^{28} 1.0 \times 10^{-7} \mathrm{M},{ }^{29} 1.2 \mathrm{ug} / \mathrm{L},{ }^{30} 1.1\right.$ $\mathrm{ugL}^{-1.31}$ ), and can be used in the direct, real-time biological assay of the brain of live fish and plant tissue. It can also be applicable for tissue monitoring, in vivo analysis and other materials requiring cadmium ion detection.

\section{Experimental Procedure}

Experimental measurements were carried out using a voltammetric system using the $\mathrm{CHI} 660 \mathrm{~A}$ instruments electrochemical workstation (from CH Instruments, Inc., Cordova, TN, USA). Multi-walled carbon nanotubes (by catalytic CVD, outside diameter: $8 \mathrm{~nm}$; inside diameter: $2-5$ $\mathrm{nm}$; length: 0.5-200 nm, Nanostructured \& Amorphous Materials, Inc. USA) were purified overnight prior to use by magnetic stirring in a $2 \mathrm{M}$ nitric acid solution and washed using triple-distilled pure water. ${ }^{32,33}$ A three-electrode system was used to monitor the voltammetric signal. The working electrode was made of paste composed of mixed carbon nanotube, metal mercury (triple distilled C\&S international. Merck index 7439-97.6) and reagent grade (Sigma) mineral oil $\left(4: 4: 2\right.$ weight ratio). ${ }^{34-36}$ The mixed paste was inserted into a plastic syringe needle type measuring $2 \mathrm{~mm}$ in diameter, with a copper wire connected to the electric system, and the set up was used as the working electrode. $\mathrm{Ag} / \mathrm{AgCl} / \mathrm{KCl}$ was used as a reference electrode and 
platinum wire was used as the auxiliary electrode. Glassy carbon electrodes (BAS stationary voltammetry electrodes MF-2012 will a 3.0-1mm diameter) were used for electrode comparison. The three-clectrode system was immersed in a solution of $10 \mathrm{~mL}$. $0.1 \mathrm{M} \mathrm{H}_{3} \mathrm{PO}_{4}$, while the other parameters were maintained at optimal conditions. All the experiments were performed at room temperature, withoul removing oxygen. Several electrolyte solutions using an acid base and buffer ( $10 \mathrm{~mL}$, each) were initially examined in search of a possible supporting electrolyte. Phosphoric acid solution was found to be the most suitable medium, yielding the best peak separation from the background currents. The concentration where the phosphoric acid was found to be most effeclive was in the range of $0.15-0.05 \mathrm{M}$. A 0.1-M-phosphoric acid concentration with a $\mathrm{pH}$ of 4,64 was found to be most suitable. Square-wave (SW) anodic stripping voltammograms were tested to determine their optimum condilions. Cadmium aceumulated on the glassy carbon electrode from -0.4 to $-0.6 \mathrm{~V}$, with cadmium peak current found in stripping voltammograms at $-0.6 \mathrm{~V}^{37.38}$ This finding was consistent with those noted in previous studies. It was also found unnecessary to carry out clectrode cleaning for every measurement. Consequently, all experiments could be performed in an open circuit. The SW stripping voltammograms used the following parameters: $300-\mathrm{H} \%$ frequency, $100 \mathrm{mV}$ amplitude, $-1.6 \mathrm{~V}$ accumulation potential, $400 \mathrm{sec}$ accumulation time, and $40 \mathrm{mV}$ increment potential. All experiments were performed at room temperature and without oxygen removal.

\section{Results and Discussion}

Comparison of cyclic voltammetric effects of cadmium peak current in PE and conventional electrode. First, the various electrolyte solutions were tested and the $0.1 \mathrm{M}$ $\mathrm{H}_{3} \mathrm{PO}_{4}$ solution yielded good results. Al this solution, common and handmade electrodes were compared. Figure 1 (A) shows the common-type glassy carbon electrode with a dianeter of $3 \mathrm{~mm}$ BAS (Model MF 2012, Bioanalytical System, USA), the peak current was around $-0.6 \mathrm{~V}$. The peak's shape and width symmetrically narrowed. This peak current showed anodic voltammetry as the best choice rather than cathodic voltanmetry, because anodic is sensitive and selective by virtue of the catalytic effects or by high complexation capacity in trace analysis. ${ }^{39-41}$ The more the cadmium was spiked, the higher the peak current became. The concentration of cadmium was changed into 10,20 , and $30 \mathrm{mgL}^{-1}$ and increased in sensitivity under the same conditions. Figure 1(B) shows the cadmium's peak signal on the raw nanotube paste electrode, which was composed of mixed carbon nanotube and mineral oil in a $4: 2$ weight ratio. The peak signal was very small, at about $-0.6 \mathrm{~V}$ on this electrode. This indicated that a smaller peak was observed in the raw nanotube than in other electrodes. Cadmium concentration of $30 \mathrm{mgL}^{-1}$ showed the highest current signal annong the other concentrations of $10 \mathrm{mgL}^{-1}$ and $20 \mathrm{mgL}^{-1}$. At this range, the peak high was increasingly saturated.
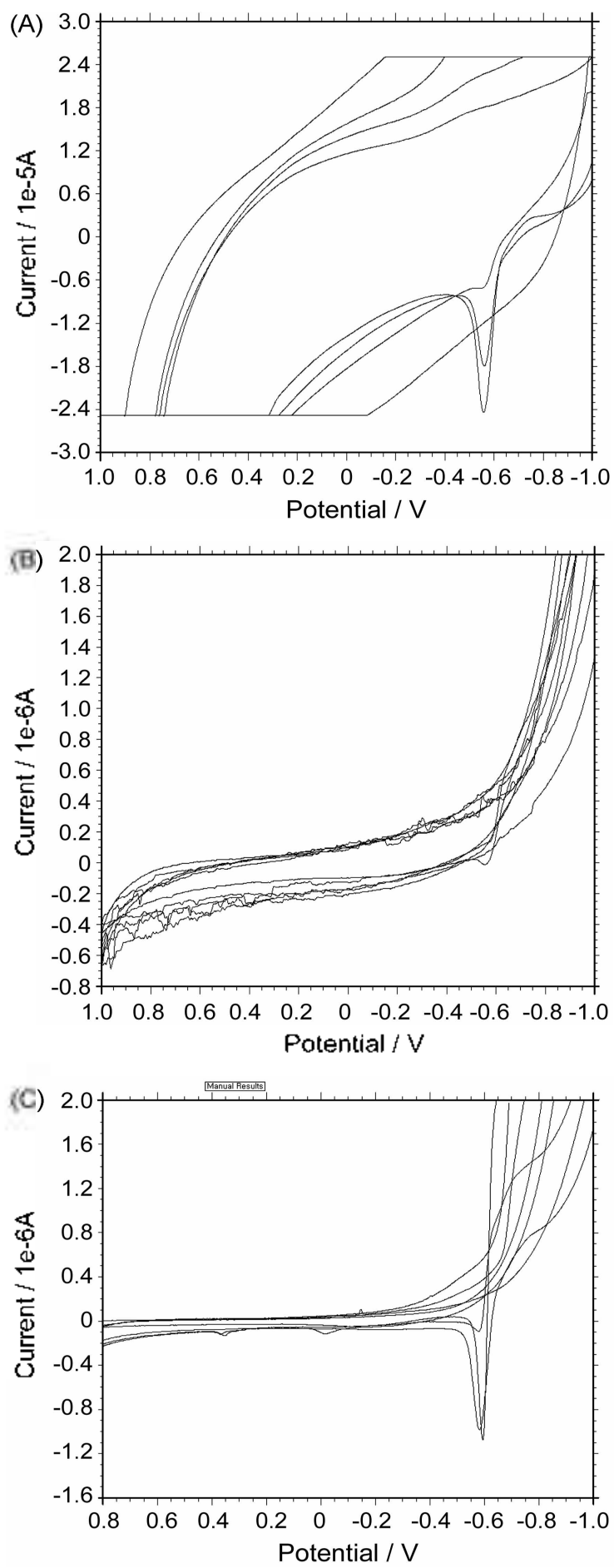

Figure 1. Comparison of sensitivity of various electrodes using $\mathrm{CV}$ with blank, 10, 20, and $30 \mathrm{mgL}^{-1}$ of cadmium spike. I1 was carried oul under optimum conditions of $-1.0 \mathrm{~V}$ initial and switching potential of $1.0 \mathrm{~V}$, with $0.5 \mathrm{~V} / \mathrm{s}$ scan rate, $(A)$ glassy carbon $(3 \mathrm{~mm}$ diameter), (B) carbon nanotube ( $1.2 \mathrm{~mm}$ diameter), and (C) PE (I.2 mm diameter), $0.1 \mathrm{M} \mathrm{H}_{3} \mathrm{PO}_{+}$electrolyle solution.

Figure 1(C) shows the increase in peak currents in the mercury-coated carbon nanotube paste electrode's sensitivity. Peak current appeared at $-0.6 \mathrm{~V}$ just as in the other electrodes. The peak signal was higher than the others as the concentration of cadmium increased. The peak signal was 
detected only through anodic voltammetry, rather than cathodic scan, which appeared sharper than other common electrodes. For the more sensitive assay, SW stripping voltammetric optimum parameters were examined in mercury-coated earbon nanolube paste electrode. With the newly made PT:, the mercury ions were immobilized onto the carbon nanotube surface using 10 repeat cyclic scan, initial potential of $2.0 \mathrm{~V}$, switching potential of $-2.0 \mathrm{~V}$ in blank electrolyte solution, which was used in the stripping voltammetry.

SW optimizations of mercury-mixed carbon nanotube paste electrode. Figure 2(A) illustrates the stripping peak current in a $0.1 \mathrm{mgI}$. ' $\mathrm{Cd}$ (II) concentration as a function of varying square-wave amplitude for the ranges of $0.1,0.15$, $0.2,0.25,0.3,0.35,0.4$, and $0.45 \mathrm{~V}$. At the $0.1 \mathrm{~V}$ range, the peak current increased very quickly, then quickly decreased at higher amplitudes of $0.15-0.45 \mathrm{~V}$, after the peak current disappeared. Subsequently, $0.1 \mathrm{~V}$ was chosen as the optimum SW amplitude. The effect of the SW aceumulation potential on the signal is shown in Figure 2(B). An examination of the influence of varying preconcentration potentials was carried out within the range of $-1.0,-1.1,-1.2,-1.3,-1.4,-1.5$, -1.6 and $-1.7 \mathrm{~V}$. The peak current appeared to be very sharp with a narrow half widls at $-1.6 \mathrm{~V}$, the cument signal increased linearly at the potential range of $-1.0 \mathrm{~V} \cdots-1.3 \mathrm{~V}$.
The peak current decreased between $-1.3 \mathrm{~V}$ and $-1.5 \mathrm{~V}$, then increased until it reached $-1.6 \mathrm{~V}$. Therefore, the optimum potential of $-1.6 \mathrm{~V}$ was chosen for the adsorptive stripping voltammetry. Figure $2(C)$ shows the results of tests on the various aceumulation times ranging from $50,100,150,200$, $250,300,350$, and 400 sec, and peak highs continued to increase at $400 \mathrm{sec}$, as subsequently used in all experiments. At this condition, other influence parameters of SW frecuency, SW increment potential, and electrolyte hydrogen ionic strength were examined (not shown here). The given was 100 ugL ${ }^{1}$ of cadmium concentration. This behavior indicated that the optimum SW frecuency was $300 \mathrm{H} /$, the optimum SW increment was $0.04 \mathrm{~V}$, and the optimum $\mathrm{pH}$ was 4.64. Al these oplimum conditions, analytical interference was studied by adding several other metal ions into 1 ppm of cadmium, 10-fold spiking was cxamined for 10 mgL, 'of chromium (sec Figure 2(D)), $10 \mathrm{mgI}{ }^{1}$ of cobalt, $10 \mathrm{mgI}{ }^{\prime}$ of iron, $10 \mathrm{mgL}{ }^{1}$ of germanium, $10 \mathrm{mgL}{ }^{1}$ of bismulh, $10 \mathrm{mgI}$. 'of calcium, and $10 \mathrm{mgL}$ ' of platinum, and resulted in $-91.36 \%,-95.68 \%,-96.52 \%,-96.31 \%$, $-93.53 \%,-77.71 \%$, and $-49.90 \%$ changes, respectively. Analylical usable working ranges and in vivo application were examined.

Analytical working ranges, statistics and application. Figure $3(\mathrm{~A})$ shows the effects of varying cadmium coneen-
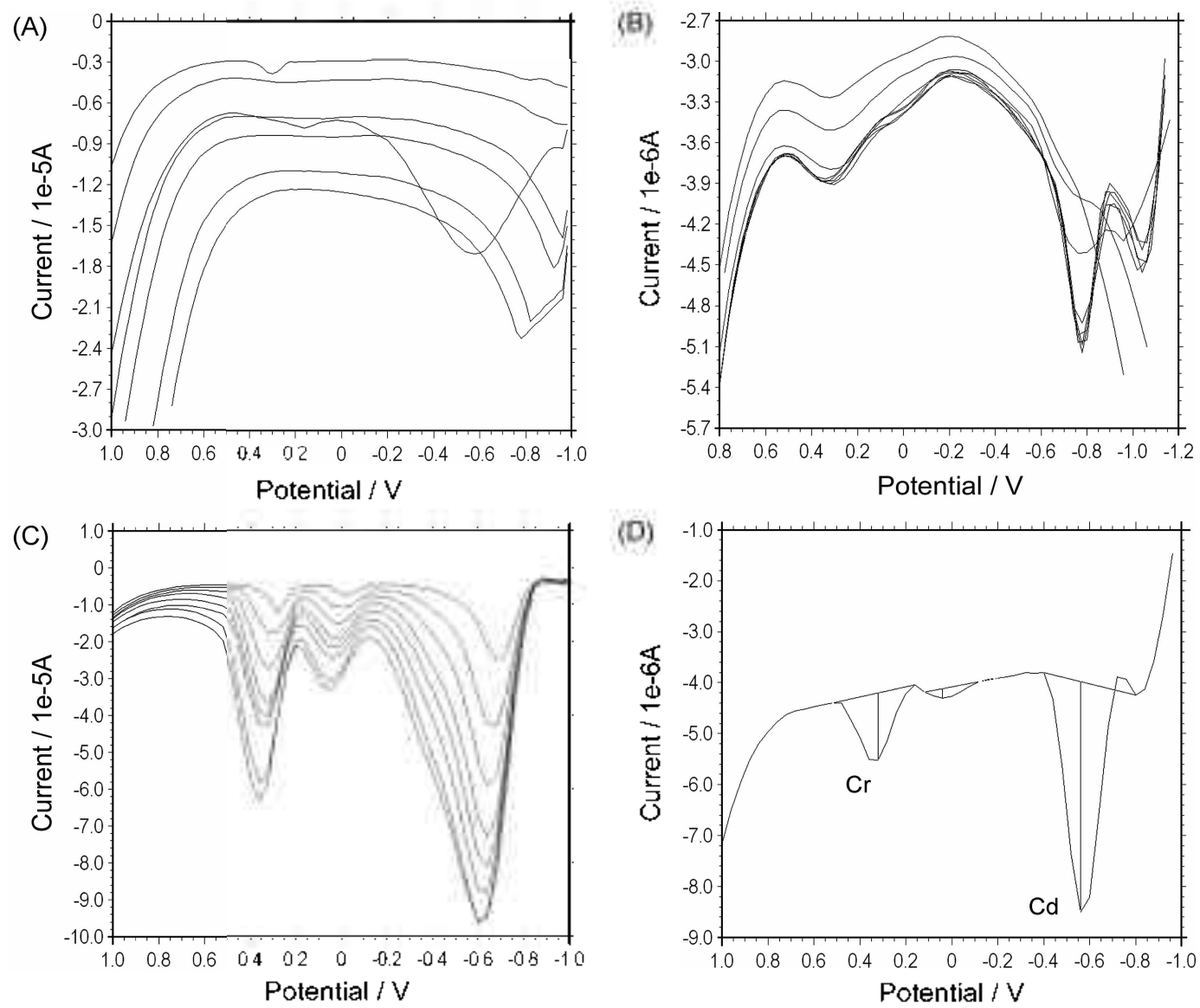

Figure 2. $(A)$ The conditions of various $S W$ amplitude ranges of $0.1 \mathrm{~V} 0.45 \mathrm{~V}$. (B) Various $S W$ aceumulation potential ranges from $1.0 \mathrm{~V}$ to - I.7 V. (C) Various $\mathrm{SW}$ accumulation times of $50-400 \mathrm{sec}, 0.1 \mathrm{mgL}^{-1} \mathrm{Cd}$ (II) spike in $0.1 \mathrm{M} \mathrm{H}_{3} \mathrm{PO}$, electrolyte solution. (D) Interference test for $10 \mathrm{mgL}{ }^{\prime} \mathrm{Cr}$ ion and $\mathrm{I} \mathrm{mgL}{ }^{\prime} \mathrm{Cd}$ (II) spike in the blank solution. Other parameters were used for the optimum conditions. 

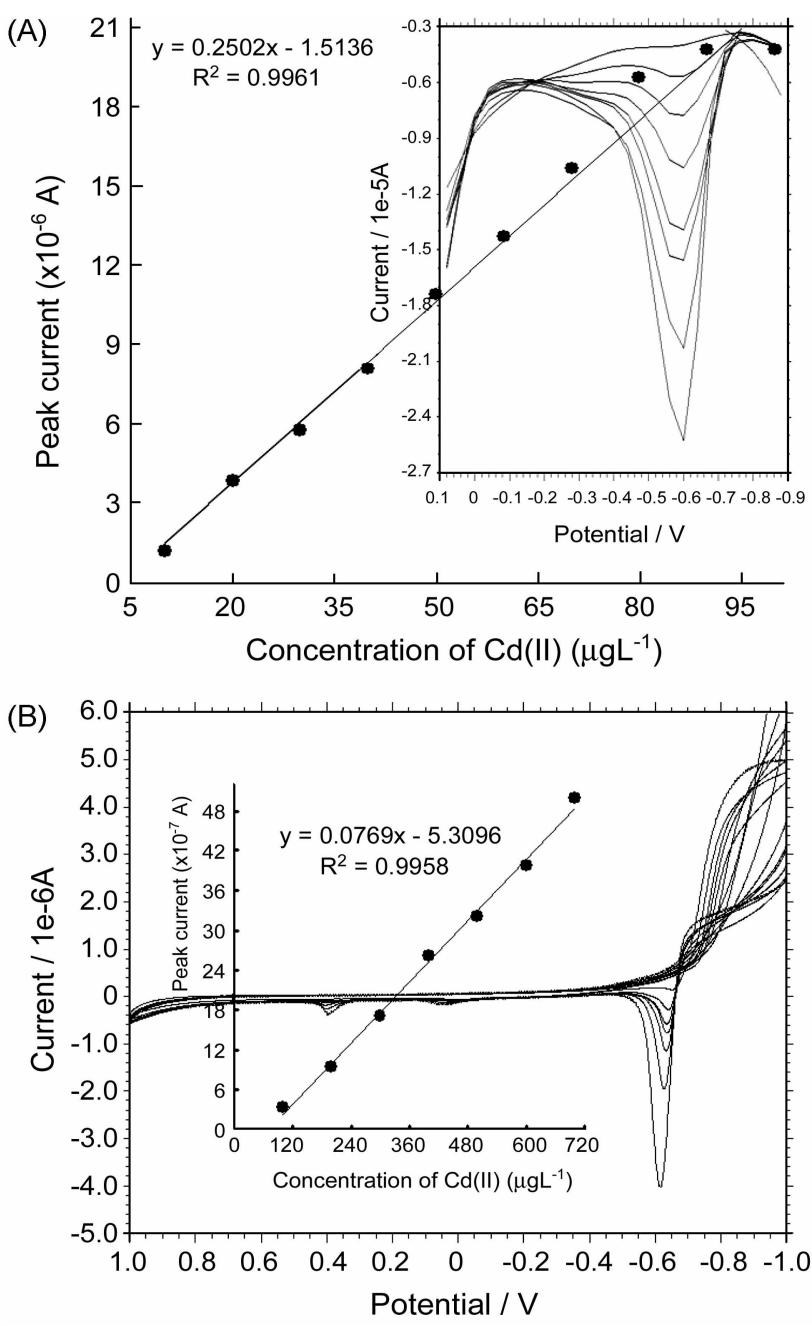

Figure 3. shows the various working ranges. (A) SW anodic concentration eflects for $0,10,20,30,40,50,60,70,80$ and 90 ugl $^{-1} \mathrm{Cd}(\mathrm{II})$; in a $0.1 \mathrm{M} \mathrm{NI} \mathrm{H}_{4} \mathrm{I}_{2} \mathrm{PO}_{4}$ solution with a $\mathrm{pH}$ of 4.64 , $\mathrm{SW}$ amplitude of $0.1 \mathrm{~V}, \mathrm{SW}$ frequency of $300 \mathrm{mV}$, an increment potential of $0.04 \mathrm{~V}$, an accumulation potential of $-1.6 \mathrm{~V}$, and an accumulation time of $100 \mathrm{sec}$. (B) The concentration ellects for 100, 200, 300, 400 500,600, and 700 ugl..$^{-1}$ Cd (II) CV. 0.1 M $\mathrm{Il}_{3} \mathrm{PO}_{4}$, electrolyte solution was used at this stage, and optimum conditions were set for other parameters.

tration ranges for $0-90 \mathrm{ugL}^{-1}$. The width of the cadmium peak narrowed at $-0.6 \mathrm{~V}$, and a linear equation was obtained for $0-80 \mathrm{ugL}^{-1} \mathrm{Cd}(\mathrm{II})$. Other ranges of the $\mathrm{CV}$ peak were obtained sharply in higher concentrations for 100-700 $\mathrm{ugL}^{-1}$. Figure 3(B) also illustrates the resultant curve of cadmium ion at $-0.6 \mathrm{~V}$ with raw $\mathrm{CV}$. In Figure $3(\mathrm{~A})$, the analytical detection limits were examined. Results show that very low detection limits of $0.6 \mathrm{ugL}^{-1} \mathrm{SW}$, according to the IUPAC recommendations $3 \sigma$ using mercury nanotube electrodes, were achieved by this method. At optimal conditions, precision testing was performed with the replicated 12 th determination of the $40.0 \mathrm{ugL}^{-1} \mathrm{Cd}$ (II) solution, from which was obtained a relative standard deviation of $0.084 \%$. These results are highly reproducible. The linear equations, statistical results, and raw voltammograms are shown in Figure 3. Finally, these were applied in the real-time assay of
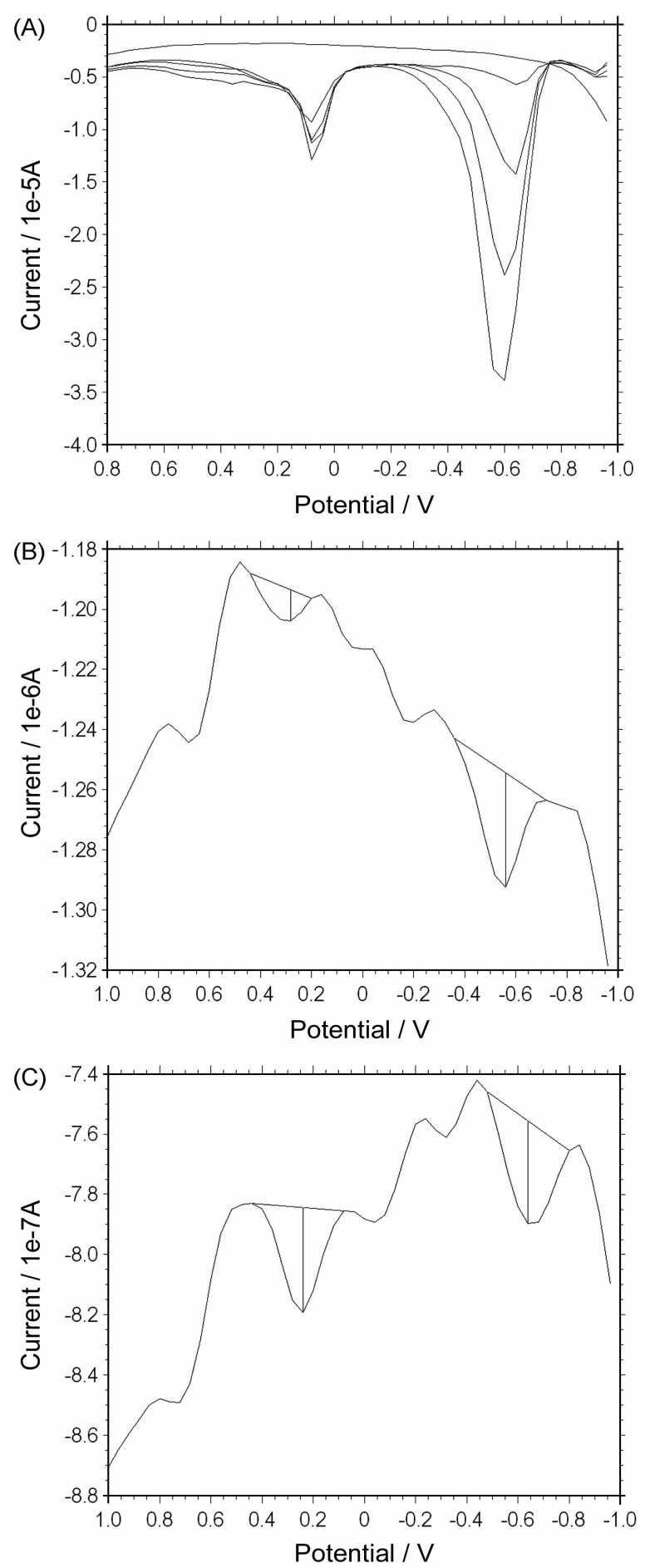

Figure 4. shows the analytical applieations. $(\Lambda)$ The standard addition methods of cadmium in the contaminated pond water sample. With optimum SW stripping voltammetric conditions: $300-\mathrm{Hz}$ frequency, $100 \mathrm{mV}$ amplitude, $-1.6 \mathrm{~V}$ accumulation potential, 400 sec accumulation time, and $40 \mathrm{mV}$ increment potential. Each curve represents the electrolyte blank solution, the $0.1 \mathrm{~mL}$ pond water spike, then the 10,20,30 ug $\mathrm{L}^{-1} \mathrm{Cd}$ (II) standard spike. (B) The cadmium peak in the live lish brain core was observed in this pond. (C) The eadmium peak in a tissue of hyacinth in this pond water was tested, with the SW parameter used for optimum conditions.

contaminated pond water samples near the city of Secul, in the brain of live fish, plant tissue samples, and water in the 
specified pond.

Analytical applications were performed in a contaminated pond water sample located near a city. A live fish brain and plant samples were also used. Figure 4(A) shows each peak based on the standard addition method with varying spikes for the blank and $0.1 \mathrm{~mL}$ water, then $10 \mathrm{ugL}^{-1}, 20 \mathrm{ugL}^{-1}$, and $30 \mathrm{ugL}^{-1} \mathrm{Cd}$ (II) spikes, on the mercury-immobilized carbon nanotube paste electrode. Results for the blank solution show that no noise signal was obtained, but a small cadmium peak was obtained after the $0.1 \mathrm{~mL}$ sample solutions were spiked. The Cd(II) with higher concentration was spiked using standard addition methods, and $0.04 \mathrm{ugL}^{-1}$ $\mathrm{Cd}(\mathrm{II}) \pm 0.007$ (RSD $4.05 \%$ ) was calculated in $0.1 \mathrm{~mL}$ water samples with repeatability factor of five. In the pond, live fish brain and plant tissue were examined. At anesthetic conditions, the PE $(1.5 \mathrm{~mm}$ in diameter, $4 \mathrm{~mm}$ in length, cylinder-type and handmade) was inserted deep $(7 \mathrm{~mm})$ into the fish's brain using a microhand drill. Then, a $0.5-\mathrm{mm}-$ diameter wire-type platinum counter and $\mathrm{Ag} / \mathrm{AgCl}, 0.5-\mathrm{mm}-$ diameter wire-type reference electrode were inserted into the fish's chest. All cables were bound with silicon adhesive. The fish specimen was transferred to a basin. After the whole process, the current signal of cadmium was checked for one week. Results show the peak signal of cadmium ion obtained at $-0.6 \mathrm{~V}$, which can be obtained in real-time assay of contaminated Cd (II) in the brain of live fish. Figure 4(B) shows the results of this examination. In this pond, the plant tissue was also examined under a real-time assay. Figure $4(\mathrm{C})$ shows the examined cadmium ion in the tissues of plants (water hyacinth). Using the same methods, three electrodes were inserted into the plant tissue. About $1 \mathrm{~min}$ later, the current signal was detected in real time with the three-electrode system in which the $\mathrm{Cd}$ (II) ion peak potential was obtained at $-0.7 \mathrm{~V}$. This was moved to the negative potential by the tissue's $\mathrm{pH}$ effect. To conclude, cadmium can be observed in all three materials. These results can be applicable in real-time assays on living tissue.

\section{Conclusion}

Low cadmium concentration was detected using squarewave stripping voltammetry with mercury-mixed carbon nanotube paste electrode. The electrode response was found to be linearly related to cadmium concentration ranging from 10 to $80.0 \mathrm{ugL}^{-1}$ at $400 \mathrm{sec}$ accumulation time. Cadmium ionic activity peaked at a $\mathrm{pH}$ of 4.64 , and various interference ions were corrected using standard addition methods. As the method used in this study had a lower detection limit of $0.6 \mathrm{ugL}^{-1}(\mathrm{~S} / \mathrm{N}=3)$, it could be used in biological real-time assays as well as on materials, pharmaceuticals, food, and drugs. It can also be applied in other fields requiring real-time cadmium analysis and monitoring.

Acknowledgement. This work was supported by grant No. (R01-2003-000-10530-0) from Korea Ministry of Science \& Technology.

\section{References}

I. Arezoo, C.; Mark, A. S.; Lawrence, M. S.; Stephen, C. B.; George, P. B. Rese. Bulle. 2001, 55, 125.

2. Mary, G.; Gail, B.; Gary, S.; Patrick, R. Soi. Tol. Emiro. 2005, $1,523$.

3. Susanne, B.; Miroslav, Z.; Carola, P.; Michael, P.; Sabine, B. Int. J. Mass Spectro. 2005, 242, 135.

4. Sergeant, M. H. V.; Deves, G.; Guillou, F. Nuc, Ins, Met in Phys. Res, B 2005, 23/, 234.

5. Jan, G; Beate, H.; Ute, S.; Ursula, V. R.; Ulf, S.; Ulrike, G. $J$. Neuro Metho. 2005, 142, 251.

6. Emest, B.; Akrt, M. C.; Dzurov, J.; Jurica, L.; Broekaert, J. A. C. Electro. 1999, 11, 1137.

7. Shohda, A. E. M.; Mohamed, Z. G.; Atef, T. F.; Mohamed, A. H. J. Bioch. and Mol. Toxi. 2001, J5, 207.

8. Bemd, K. Electro. 2005, 1.

9. Gunnar, N. J. Tra. Ele. Expe. Medicine 2003, 16, 307.

10. Hardcastle, J. L.; West, C. E.; Compton, R. G. Anal. 2002, 127, 1495 .

11. Khodari, M. Electroa 1998, 10(15), 1061.

12. Famei, L.; Dandan, Z,; Xiumei, L.; Yuling, W.; Zhili, X. Bio. Chrom. 2004, 18,866 .

13. Ling, X.; Xiumin, S.; Cong, Z.; Koichi, M. Chrai. 2005, $17,476$.

14. Jeffry, B. P.; Mila, L.; Raymond, E. M, I. T. MS of Dioxins/Furans and $P C B$ s $2000,19,305$.

15. Pawel, L.U.; Carmen, G. R.; Ma, G; Ma, L. M, J. Sep. Sci. 2005, 28.

16. Markus, J.; Peter, G; Gerd, U. F.; Joseph, W. Electroa. 2001, Is(1), 34 .

17. Pompilia, S.; Marisol, V.; Liviu, R. J. Phar Biome. Analy: 2000. 23,99 .

18. Lin, L.; Sompong, T.; Joseph, W.; Yuehe, L.; Omowunmi, A. S.; Suw, Y. L. Ana. Chi. Acta $2005,535,9$.

19. Suw, Y. L.; Sang, S. S.; Sung, K. K.; Young, S. J.; Chang, H. L. F. Chemi. 2006, 95, 337.

20. Francesco, R.; Carla, G. A.; Aziz, A.; Lo, G.; Giuseppe, P.; Danila, M. Electro. 2003, 15, 1204

2I. Soo, B. K.; Si, X, G. Electro. 2002, $14,813$.

22. Suw, Y. L.; Duck, H. K.; Myung, H. K. Talanta 2002, $58,919$.

23. Jyh, M. Z.; Hsieh, H. C.; Govindasamy, I. Electro. 1999, $/ 1,108$.

24. Percio, A. M. F.; Angela, L. R. W.; Margarida, B. R. B.; Adriana, T. S.; Arnaldo, A. C. Tala. 2003, 61,829.

25. Joseph, W.; Samo, B. H.; Bozidar, O. Electro. Comm. 2004, 6 , 176.

26. Bailure, S. S.; Wlodzimierz, K.; Francis, D. S. Electro, 2003, 15, 753.

27. Eugenii, K.; Itamar, W. Chem. Ph: 2004, 5, 1084.

28. Chengguo, H.; Kangbing. W.; Xuan, D.; Shengshui, H. Tal. 2003, 60,17 .

29. Glimaldo, M.; Ma'rcio, F. B.; Marcos, F. S. T.; E'der, T. G. C. Tal. $2003,50,1021$

30. Samo, B. H.; Ivan, S.; Karel, V.; Bozidar, O. Electro. Act 2005, 51, 706.

31. Kidane. F.; Bhagwan. S. C. Electro. 2001. 13, 484 .

32. Randhir, P. D.; Joseph, W. Electro. Commu. 2004, 6, 284.

33. Joseph, W.; Samo, B. H.; Bozidar, O. Electro. Com, 2004, 6, 176.

34. Joshua, O.; Philippe, W; Tebello, N. Electro. 2002, 14, 1165.

35. Wilson, T. L. S.; Christine. T. G.; Maria, O. O. R.; Nabil. E. M. Electro. 2002, 14, 71 .

36. Korbut. Q.; Buckova, M.; Tarapcik, P.; Labuda. J.; Grundler, P. $J$. Ele. $L$ Che. $2001,506,143$.

37. Khodar, M. Electroan, 1998,10, 1061.

38. Frank, M.; Steven, L. M.; Richard, G C.; Barty, A. C. Electro. 2000. 12.267

39. Pompilia, S.; Marisol, V.; Liviu, R. J. Pha. Bio Ana. 2000, 23, 99.

40. Eric, F.; Constant, M. G. B. Anal. Chi. As. 1999, 385, 273.

4I. Biji, F. J. C.; Sluyters, M.; Sluyters, J. H. J. Ele. Che. 1997, 435, 137. 